Linguistik Terapan 16 (3) (2019): 510 - 517

Jurnal Linguistik Terapan Pascasarjana

Available online

http://jurnal.unimed.ac.id/2019/index.php/JLT-Unimed

\title{
IDEATIONAL GRAMMATICAL METAPHORS IN EDITORIALS TEXTS OF THE JAKARTA POST NEWSPAPER
}

\author{
Kiky Wardhani
}

Siti Aisyah Ginting

Sumarsih

\author{
English Applied Linguistics Program
}

Postgraduate Program - Universitas Negeri Medan

Diterima September 2019; Disetujui Oktober 2019; Dipublikasikan Desember 2019

\begin{abstract}
This study was investigated the realization of ideational grammatical metaphors in editorials of The Jakarta Post Newspaper. The objectives of this study were to identify the types of ideational grammatical metaphor are found in editorials texts of, to describe how the ideational grammatical metaphor lingustically realized in the editorials text, and to explain the reasons for the used of ideational grammatical metaphors. This study was conducted by using descriptive qualitative research. The sourceof data were editorials of The Jakarta Post newspaper, published on http://www.thejakartapost.com/chanel/editorial, which containing of six editorials written in January 2015 episode. The data were the texts containing of ideational grammatical metaphors. The data were analyzed based on the Sistemic Functional Language approach. The result showed that there were four types of ideational grammatical metaphor, namely adjective $=>$ noun, verb $=>$ noun, verb $=>$ adjective, adverb $=>$ adjective. The dominant type of ideational grammatical metaphor in the editorials is verb $=>$ adjective. The reasons of ideational grammatical metaphor used in the editorials was due to nominalization and condensation. Grammatical metaphor as a model of language was needed to help people to understand how a text work to make meaning and all meaning was situated in context of situation and context of culture. There was a great deal of variation among different register in the degree and types of metaphor that was encountered. Register of field is social action of which is going on the text of editorials texts.
\end{abstract}

Key words: Ideational Grammatical Metaphor, Texts, The Jakarta Post newspaper,

How to Cite: Wardhani, Kiky (2019).

Ideational Grammatical Metaphors In Editorials Texts of The Jakarta Post Newspaper. Jurnal Linguistik Terapan Pascasarjana Unimed, 16 (3): 510 - 517 
ltbi2kiky@gmail.com

\section{INTRODUCTION}

Grammatical metaphor is needed to help people to understand how text creates meaning and all meanings are situated in context of situation. The study of the uses of grammatical metaphor is particularly useful in revealing how process are changed into object. Grammatical metaphor in this case changes not only the grammar of the text but also the reader's reaction to texts. Further discussion, Halliday (1985:321) makes a distinction between two main types of grammatical metaphor: interpersonal metaphors (or metaphors of mood), and ideational metaphors (or metaphors of transitivity), which ideational grammatical metaphor (IGM) includes process types and nominalization; only ideational grammatical metaphors of latter kind will concern us in this paper. The most common form of ideational grammatical metaphor seems to be nominalization, which is a characteristic feature of scientific texts. According to Halliday (2004), "nominalization is the single most powerful resource for creating grammatical metaphor".

A newspaper is 'living textbooks'. A newspaper is a publication that is issued daily or weekly and includes local and international news stories, advertisement, announcement, opinions, sport news, business and political news, editorial text and many other interesting news. With the spread of education, the popularity and importance of newspapers have increased by leaps and bounds. Everybody today wants to read a newspaper. The language of mainstream newspaper is formal and special English so, there is no surprise that the grammatical metaphor identification procedure can be obviously applied to newspaper text. Using grammatical metaphor in newspapers satiesfies with readers' curiosity and excitement but sometimes causes many difficulties for us to understand. So, because the function of grammatical metaphor is to avoid the misunderstanding in conveying messages, texts which 
employ ideational grammatical metapore in its certain text would be better thatn the one which do not. In brief, the ability to employ grammatical metaphor becomes one of the critical success factors in delivering points in texts.

From the explanation about the difficulties of English language in newspaper above was related to the following examples from the first observation as preliminary were:

1. Congruent: "Credit should go to those involved in the efforts massively in search of an Air Asia plane."

The metaphorical wording: "Credit should go to those involved in the massive efforts in search of an Air Asia plane." (type 13(ii) adverb=> adjectives)

The shift that included in this type was grammatical shifted from adverb into adjective or from semantic shifted point of view was the shifted from thing into expansion of thing. Semantically from circumstance into the expansion of things.

2. Congruent: "President Jokowi will move closer to fulfill such expectations Many people have criticized the ideas."

Metaphorical wording: "President Jokowi will move closer to fulfilling such expectations" (type 2: verb => noun)

The shift of ideational grammatical metaphor type 2 is grammatically shifted from verb into noun and semantically shifted from process into thing.

The problem of the readers or listeners is they face difficulties in understanding the message of the text of editorial. By identifying the ideational metaphor in editorial of Jakarta Post newspaper, the readers have better understanding to mean the message of editorial of Jakarta Post newspaper. The researcher chose the editorial of Jakarta Post which is from 2014, (episode: December 2014to January 2015). Trough this research the researcher wants to know the types of Ideational metaphor used in this text of editorial. 


\section{RESEARCH METHOD}

This research was conducted by using descriptive qualitative method. This analysis based on SLF theory and the study is concerned with the application of SLF theory in Ideational Grammatical Metaphor. The source of the data of this study were editorials of The Jakarta Post, as one of English written newspaper published in Indonesia. This study was conducted by using descriptive qualitative research. The data would be taken from $25 \%$ of episode January2015.So, there were six editorials that the researcher was taken as the sources of the data. And the editorials were taken randomly on every week of the month. The data were collected by doing documentary technique. The data were accessed from editorial articles in its official website of The Jakarta Post newspaper on http://www.thejakartapost.com/channel /editorial. The researcher applied the theory and the data were analyzed by ideational grammatical metaphor and the types of ideational grammatical metaphor. The instrument of the data collection was used to gather information based on the instrument of the research. The Jakarta Post newspaper was used as the medium to conduct the analysis. The researcher acted as participant observer. The data must be auditable in qualitative research. The aim of trustworthiness of a research study was important to support the argument that the in quirt's findings were worth paying attention to (Lincoln and Guba, 1985:200). It can be achieved through checking the credibility, transferability, dependability, and conformability. The data will be analyzed through the interactive model of Miles, Huberman and Saldana (Miles, Huberman and Saldana, 2014). Namely data collection, data condensation, data display and data conclusion. It can be seen in the following figure. 


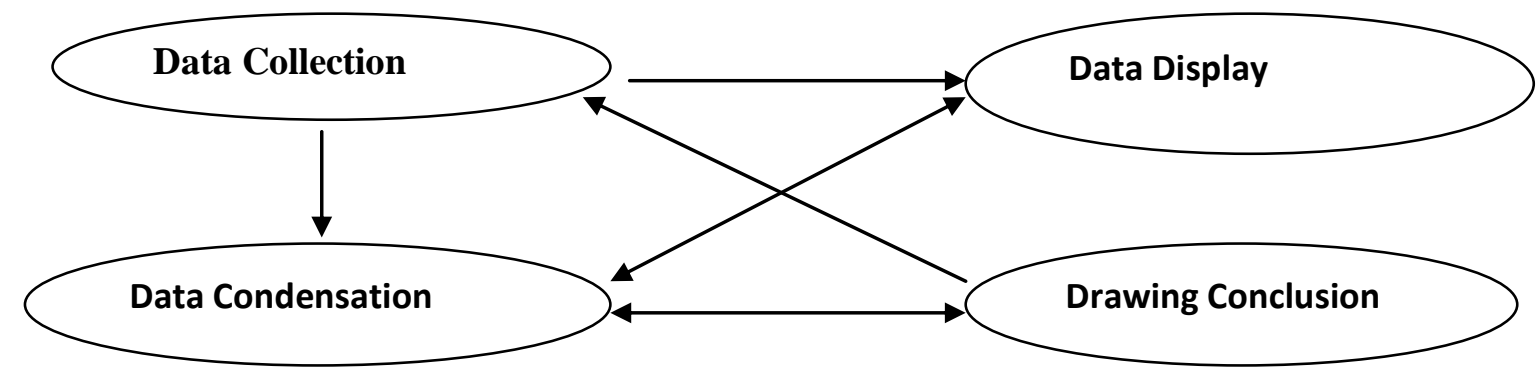

Figure: 1: Component of Data Analysis: Interactive Model taken from Miles, Huberman and Sladana

\section{FINDINGS AND DISCUSSIONS}

The data of this study were ideational grammatical metaphors realized by types of ideational grammatical metaphors taken from the editorials of The Jakarta Post newspaper. There were 38of ideational grammatical metaphors to be analyzed. The data were analyzed based on the use of ideational grammatical metaphors in systemic Functional Linguistics (SFL) theory. After analyzing the ideational grammatical metaphor in editorial texts, the findings are elaborated in the following subsections.

\section{Types of Ideational Grammatical Metaphors Used in Editorials Texts of The Jakarta Post newspaper}

The following table was the data of kinds of ideational grammatical metaphors in editorials texts of The Jakarta Post newspaper. The ideational grammatical metaphor can be classified into thirteen types that has been explained in the chapter two. After identifying the ideational grammatical metaphors in editorials texts of The Jakarta Post newspaper, it was found that there are four types of ideational grammatical metaphor they were type 1 (Adjective $=>$ Noun), type 2(Verb $=>$ Noun), type 5 (Verb $\Rightarrow$ Adjective) and type 13 (ii) ( Adverb $=>$ Adjective). For make it clear, the kinds of ideational grammatical metaphor in editorials texts in The Jakarta Post newspaper can be seen in the table 1 as follows: 
Table 1: Data Analysis of Ideational Grammatical Metaphors

\begin{tabular}{|c|c|c|}
\hline No & Types of IGM & $\begin{array}{l}\text { The Data } \\
\end{array}$ \\
\hline 1 & $\begin{array}{l}\text { Adjective => Noun } \\
\text { (type } 1 \text { ) }\end{array}$ & $\begin{array}{l}\text { 1) "The ongoing operation can serve as a model for } \\
\text { future search and rescue efforts". } \\
\text { 2) "Despite our differences on media responsibilities } \\
\text { under freedom of speech," }\end{array}$ \\
\hline 2 & $\begin{array}{l}\text { Verb => Noun } \\
\text { (type 2) }\end{array}$ & $\begin{array}{l}\text { 1) "a lecturer faces intimidation and death threats for } \\
\text { taking students to a church" } \\
\text { 2) "SKK Migas provided a tanker, allowing the } \\
\text { search and rescue fleet to refuel without having to } \\
\text { leave the operational area" }\end{array}$ \\
\hline 3 & $\begin{array}{l}\text { Verb } \Rightarrow>\text { Adjective } \\
\text { (type 5) }\end{array}$ & $\begin{array}{l}\text { 1) "In a letter date Nov. 24, 2014, sent to all } \\
\text { governors, regents, mayors and DPRDs across the } \\
\text { country," } \\
\text { 2) "The announcement of the new fuel pricing policy } \\
\text { last week still left one question...." }\end{array}$ \\
\hline 4 & $\begin{array}{l}\text { (ii) Adverb => } \\
\text { Adjective } \\
\text { (type } 13 \text { (ii)) }\end{array}$ & $\begin{array}{l}\text { 1) "This policy instead will ensured gradual" } \\
\text { 2) "The question, rather, is how Jokowi can make full } \\
\text { use of the TNI's younger generation" }\end{array}$ \\
\hline
\end{tabular}

There were four types of ideational grammatical metaphor in editorials texts of The Jakarta Post newspaper are adjective=>noun $(5.26 \%)$,verb $=>$ noun $(18.42 \%)$, verb=>adjective $(63.16 \%)$, and adverb=>adjective $(13.16 \%)$.

\section{DISCUSSION}

Halliday and Matthiessen (1999:246) identify the types of ideational grammatical metaphor and characterize them explicitly in relation to the semantics as a whole. As a result, there were 13types of ideational grammatical metaphors have been identified. They were 1) Adjective $=>$ noun, 2) verb $=>$ noun, 3) preposition (al phrase) $\Rightarrow>$ noun, 4) conjunction $=>$ noun, 5) verb =>adjective, 6) preposition (al phrase) $\Rightarrow$ adjective, 7) conjunction => adjective, 8) preposition (al (phrase) $=>$ verb, 9) conjunction =>verb, 10) conjunction => preposition (al phrase), 11) + noun,12) + verb, 13) (i) noun =>various, and (ii) adverb => adjective. After analyzing the data, it found that there were four types of ideational grammatical metaphors that realized in editorials texts of The Jakarta Post newspaper. They were: (1) adjective $=>$ noun(2) verb $=>$ noun (3) preposition (al phrase) $=>$ noun (4) conjunction =>noun (5) verb =>adjective (6) preposition (al phrase) (7) conjunction 
=>adjective (8) preposition (al phrase) => verb (9)conjunction =>verb (10) conjunction $=>$ preposition (al phrase) (11) +noun (12) +verb (13) (i)noun =>various, and (ii) adverb $=>$ adjective. After analyzing the data, it found that there are four types of ideational grammatical metaphor that realized in editorials texts of The Jakarta Post newspaper. They are type 1 (adjective =>noun), type 2 (verb =>noun), type 5 (verb =>adjective), and type 13 (ii) (adverb =>adjective). It happened since nominalization was the single most powerful resource for creating grammatical metaphor. On the other hand, other types of ideational grammatical metaphor are rarely realized in discourse and speech.

\section{CONCLUSION}

The main purpose of the study is to describe the types of ideational grammatical metaphors used in the editorials text of The Jakarta Post. There were four types of ideational grammatical metaphors that found in editorials texts of The Jakarta Post newspaper. They are type 1 (adjective=>noun), type 2 (verb =>noun), type 5 (verb =>adjective), and type 13 (ii) (adverb =>adjective).The field of this study needs to be limited to analyze ideational grammatical metaphors in the editorials text of The Jakarta Post newspaper. The researcher took the editorials text within the topic are about Cabinet Bureaucratic of Indonesian country.

\section{REFERENCES}

Barus, S. W. (2010). Jurnalistik: Petunjuk Teknis Menulis Berita. Jakarta: Erlangga

Bonyadi, A. and Samuel, M. (2013). Headlines in Newspaper Editorials: A Contrastive Study.

\section{SAGE}

Crystal, D., \& Davy, D. (1969). Studies in the History and Theory of Linguistics. IndianUniversity

Garrett, R. K. (2006). Protest in an Information Society: A Review of Literature on SocialMovements and New ICTs. Information, Communication and Society.

Halliday, M. A. K. (1985). An Introduction to Functional Grammar. London: Edward Arnold.

Halliday, M. A. K., \& Matthiessen, C. (1999). Construing experience through meaning: Alanguagebased approach to cognition. London/New York: Cassell.

Halliday, M. A. K., \& Matthiessen, C. M. I. (2004). An Introduction to Functional Grammar.London: Routledge.

Lincoln, Y. S., \& Guba, E. G. (1985). Naturalistic inquiry. Beverly Hills, CA: Sage.

Miles, M. B., A. Michael H., and Johnny S. (2014). Qualitative Data Analysis: A Methods

Sourcebook. Thousand Oaks, CA: Sage.

Ratnanto, N. (2010). “Kohesi Gramatikal dan Leksikal Editorial The Jakarta Post”. Tesis.

Program Pascasarjana Universitas Sebelas Maret Surakarta.

Saragih, A. (2010). Semiotik Bahasa: Tanda, Penanda dan Petanda Dalam Bahasa. FakultasBahasa. 
Pascasarjana Universitas Negeri Medan.

Simmons, B. A., Frank D., and Geoffrey G. (2006). Introduction: the international diffusion of liberalism. International Organization, 60 (4): 781-810.

The Jakarta Post. January 5th, (2015). Teamwork counts, p.6. in http://www.thejakartapost.com/news/2015/01/05/editorial-teamworkcounts.html\#sthash. TXq7wGv8.dpuf

The Jakarta Post. January 7th, (2015). Fight Repression, p.6. in http://www.thejakartapost.com/news/2015/01/07/editorial-defenserevolution.html \#sthash.7jlhNPbh.dpuf

The Jakarta Post. January 9th, (2015). Delayed Budget Approval, p.6. in http://www.thejakartapost.com/news/2015/01/09/editorial-fightrepression.html\# sthash.kngQDdGi.dpuf

The Jakarta Post. January 12th, (2015). It Is Managed Floating, p.6. in http://www.thejakarpost.com.news/2015/01/12/editorial-delayed-badgetapproval.html \#sthash.ZyT07rgy.dpuf

The Jakarta Post. January 15th, (2015). Defense Revolusion, p.6. in http://www.thejakartapost.com/news/2015/01/15/editorial-it-managedfloating.html\# stash.PCZBPz4E.dpuf

The Jakarta Post. January 20th, (2015). Fighting Dirty Money, p.6. in http://www.thejakartapost.com/news/2015/01/08/editorial-fighting-dirtymoney.html\#sthash. owVGE2IR.dpuf

Thompson, G, (1996). Introducing Functional Grammar. London: Edward Arnold 